\author{
Tomasz Leś \\ Instytut Pedagogiki, Wydział Filozoficzny, Uniwersytet Jagielloński \\ E-MAIL: tomasz.les@uj.edu.pl \\ Małgorzata Kozak \\ Instytut Pedagogiki, Wydział Filozoficzny, Uniwersytet Jagielloński \\ E-MAIL: kozakmalgorzata@wp.pl
}

\title{
Filozoficzno-prawne aspekty uzasadnienia prawa do równości w edukacji
}

\section{STRESZCZENIE}

W artykule została dokonana analiza problematyki uzasadniania prawa do równości w edukacji (rozumiane jako prawo do równości do bycia edukowanym). Prezentowane analizy dotyczą wybranych kwestii związanych z tym zagadnieniem, takich jak: problem relacyjności i normatywności pojęcia równości i prawa do edukacji; problem możliwości uzasadnienia prawa do równości w edukacji; uzasadnienie wspomnianego prawa w ustawodawstwie polskim i międzynarodowym. Zaznacza się również wybrane kwestie historyczne (tj. próby uzasadnienia prawa do równości w edukacji na gruncie szeroko rozumianej myśli filozoficznej) i praktyczne (tj. bariery w jego realizacji).

SŁOWA KLUCZOWE: prawo do równości w edukacji, prawo a edukacja, prawo do edukacji, normatywność edukacji, prawne aspekty edukacji, filozoficzne aspekty edukacji.

Problem równości w edukacji jest zagadnieniem na tyle szerokim, że z powodzeniem może być (i w praktyce jest) podejmowany w ramach różnych dyscyplin wiedzy, w szczególności humanistycznych i społecznych (w tym prawnych). Badania mogą dotyczyć samego pojęcia równości i jego relacji do innych pojęć (np. dobra i sprawiedliwości), historycznego i społecznego kontekstu równości, jego funkcji społecznej i psychologicznej, genezy ewolucyjnej, czy umocowania normatywnego w prawie pozytywnym. Pedagogiczny aspekt tego pojęcia jest specyficzny; jego analiza powinna uwzględniać większość z powyższych. Trudno jednak wyobrazić sobie rzetelne zdanie sprawy z pedagogicznego aspektu równości, bez uzasadnienia samej wartości równości, funkcji społecznej i psychologicznej, czy prawa danego państwa. Ana- 
lizy równości w edukacji ${ }^{1}$ wymagają zatem szerokich badań, problematyzowanych dodatkowo przez normatywność tego pojęcia. Artykuł ten dotyczy jedynie wybranych, podstawowych aspektów możliwych badań. Jego celem jest dokonanie analizy zagadnienia uzasadnienia prawa do równości w edukacji $^{2}$ w kontekście filozoficzno-prawnym. Analizy te mogą stać się podstawą do dalszego namysłu nad funkcjonowaniem tej zasady w rzeczywistości edukacyjnej i projektowania jej zmian.

W ramach niniejszego artykułu zaprezentowane zostaną następujące kwestie:

(a) podstawowe problemy związane $\mathrm{z}$ uzasadnieniem prawa do równości w edukacji, uwzględniające w szczególności relacyjny i normatywny aspekt zasady równości i prawa do edukacji (w tym, podejmowane w historii filozofii próby uzasadnienia wspomnianego prawa) oraz

(b) analizy zabezpieczającego zasadę równości ustawodawstwa polskiego ( $w$ tym, faktyczne bariery $\mathrm{w}$ realizacji tej zasady na gruncie polskiego systemu oświaty).

\section{Równość i prawo do edukacji}

Samo pojęcie równości używane jest na różne sposoby, występuje zarówno w języku potocznym, jak i naukowym. Jest pojęciem wieloznacznym. Mówimy np. że osoba $A$ jest równego wzrostu wobec $B$ albo że obiekt $X$ jest równy długości $Y$, w innych kontekstach mówi się, że $A$ powinien mieć równe prawa w stosunku do $B$ (np. do wolności wypowiedzi, religii itp.). W pierwszych dwóch przypadkach równość występuje w zdaniach opisowych (stwierdzających stan rzeczy), w ostatnim - w zdaniach normatywnych (stwierdzających pożądany stan rzeczy). Równość funkcjonuje tu zatem jako zasada normatywna. $\mathrm{Z}$ perspektywy celu tego artykułu interesujący jest ten normatywny aspekt pojęcia równości, wyrażany w zasadzie: $A$ powinien mieć równe prawo do edukacji w stosunku do $B$. Już taka pobieżna analiza pojęciowa wskazuje dodatkowo na relacyjność tego pojęcia, tj. $A$ jest (powinien być) równy wobec $B$. Należy zwrócić uwagę na fakt, że równość orzekamy ze względu na coś; w omawianym przypadku kryterium tym jest prawo do edukacji. Równość zdefiniować można zatem w następujący sposób: $A$ jest (powinien być) równy $B$ ze względu na $C$ wtedy i tylko wtedy, gdy $A$ i $B$ są (powinny być) tożsame ze względu na niektóre (co najmniej jeden, ale nie

\footnotetext{
„Równość w edukacji” rozumie się tu w sensie równości do bycia edukowanym.

2 „Edukację” rozumie się tu jako „ogół procesów oświatowo-wychowawczych, obejmujących kształcenie i wychowanie oraz szeroko pojmowaną oświatę”, W. Okoń, Nowy słownik pedagogiczny, Wydawnictwo Edukacyjne Żak, Warszawa 1995, s. 64.
} 
wszystkie) własności. Mamy zatem do czynienia z relacją trójczłonową: $A$ jest (powinien być) równy $B$ ze względu na $C$. Człony $A$ i $B$ tej relacji to podmioty edukacji, z kolei $C$, to ze względu na co $A$ i $B$ są (powinni być) równi (tutaj: prawo do edukacji).

Podobnie z pojęciem prawa. Jest ono używane w różnych kontekstach. Po pierwsze, może być to zbiór norm prawnych (pozytywnych) obowiązujących np. w danym państwie. Po drugie, kiedy mówimy, że osoba $A$ ma prawo do $X$, możemy to rozumieć na co najmniej następujące sposoby: jako (a) możliwość realizacji określonego zachowania, wynikającą z prawa pozytywnego (np. „Mam prawo do podjęcia pracy w krajach Unii Europejskiej”); (b) powinność realizacji pożądanej (w sensie moralnym) własności (np. „Mam prawo do bycia szanowanym"). W przypadku nierealizacji prawa $A$ do $X$, nastąpić mogą sankcje prawne (jak w (a)) lub moralne (jak w (b)). Niektóre prawa typu (a) są zarazem prawem typu (b) w tym sensie, że z powodu ich nierealizacji dodatkowo mogą grozić sankcje prawne (i odwrotnie). Prawo do równości w edukacji może być prawem tego rodzaju, tj. zarówno (a) jak i (b). Uniemożliwienie dziecku dostępu do edukacji może grozić sankcjami zarówno moralnymi, jak i administracyjno-prawnymi wobec m.in. jego rodziców bądź opiekunów prawnych.

Niniejsze analizy wymagają również doprecyzowania definicyjnego podejmowanej w nich kategorii „prawa dziecka do edukacji”. Spojrzenie na edukację $\mathrm{w}$ ujęciu praw podmiotowych jednostki wymaga nakreślenia szerszego kontekstu związanego $\mathrm{z}$ procesem inkluzji prawnej problematyki edukacji. Przez wieki bowiem procesy nauczania, uczenia się i kształcenia nie były analizowane w aspekcie uprawnień podmiotu: dziecka, człowieka, a jedynie w perspektywie możliwości, powinności czy zobowiązań kierowanych do wybranych jednostek czy grup społecznych. Sama edukacja dziecka nie była postrzegana w kategoriach wartości uniwersalnej, zatem w sposób naturalny nie była zabezpieczana przez prawo pozytywne. Dopiero stopniowe procesy przewartościowania kategorii dzieciństwa, zmiana wizerunku społecznego dziecka, jego pozycji w rodzinie i społeczeństwie, rozwój etyki filozoficznej i podstawowych pojęć związanych z prawami człowieka, rozwój działalności międzynarodowych instytucji i organizacji zajmujących się ochroną dziecka, doprowadziły ostatecznie do wyartykułowania i uznania edukacji jako normy powszechnie obowiązującej , najpierw społecznie, a później również prawnie. Obecnie problematyka edukacji dziecka odnalazła swoje zabezpie-

S. Hart, C. P. Cohen, M. F. Erickson, M. Flekkøy, Prawa dzieci w edukacji, przekł. S. Pikiel, GWP, Gdańsk 2006, s. 223. 
czenie normatywne w większości europejskich konstytucji. Stopniowo w debacie publicznej i naukowej można było obserwować także tendencje przypisujące edukacji rolę jednej z podstawowych przesłanek do realizacji pozostałych praw i wolności człowieka ${ }^{4}$. W edukacji zaczęto upatrywać dobra społecznego, perspektywy możliwości rozwoju potencjału jednostki i całego społeczeństwa. Momentem przełomowym w procesie tworzenia podstaw dla edukacji jako standardu w zakresie prawa międzynarodowego była uchwała Zgromadzenia Ogólnego Narodów Zjednoczonych numer 217A (III) z dnia 10 grudnia 1948 roku, przyjmująca Powszechną Deklarację Praw CzŁoWIEKA5. Artykuł 26 Deklaracji stanowi, że nauka jest podstawowym prawem każdego człowieka oraz że jest ona bezpłatna i obowiązkowa przynajmniej na szczeblu podstawowym. Problematyka prawa człowieka do nauki znalazła swoje miejsce $w$ wielu dokumentach i deklaracjach międzynarodowych, jak chociażby w Międzynarodowym Pakcie Praw Gospodarczych, SPOEECZNYCH I KuLTURALNYCH.

Jednakże pełne doprecyzowanie, dookreślenie i zabezpieczenie prawa dziecka do edukacji wymagało wiele trudu i zabiegów poszczególnych państw i społeczności międzynarodowej. Ostatecznie pełny kształt koncepcji prawa dziecka do edukacji został określony w artykułach 28 i 29 KonwENCjI O PRAWACH DZIECKA, przyjętej przez Zgromadzenie Ogólne Narodów Zjednoczonych 20 listopada 1989 roku. Już punkt pierwszy artykułu 28 zwraca uwagę na przedmiotową kategorię wyznaczającą obszar niniejszych rozważań:

Artykuł $28^{6}$

1. Państwa-Strony uznają prawo dziecka do nauki i w celu stopniowego realizowania tego prawa na zasadzie równych szans, w szczególności:

a) uczynią nauczanie podstawowe obowiązkowym i bezpłatnym dla wszystkich;

b) będą popierać rozwój różnorodnych form szkolnictwa średniego, zarówno ogólnokształcącego, jak i zawodowego, uczynią je dostępnymi dla każdego dziecka oraz podejmą odpowiednie kroki, takie jak wprowadzenie bezpłatnego nauczania oraz udzielanie w razie potrzeby pomocy finansowej;

c) za pomocą wszelkich właściwych środków uczynią szkolnictwo wyższe dostępnym dla wszystkich na zasadzie zdolności;

d) udostępnią wszystkim dzieciom informacje i poradnictwo szkolne i zawodowe;

e) podejmą kroki na rzecz zapewnienia regularnego uczęszczania do szkół oraz zmniejszenia wskaźnika porzucania nauki.

4 J. Mikosz, Prawo do nauki, [w:] Prawa człowieka. Model prawny, R. Wieruszewski (red.), Ossolineum, Wrocław 1991, s. 979.

5 Powszechna Deklaracja Praw Człowieka, źródło: http://libr.sejm.gov.pl/teko1/txt/onz/1948. html.

6 Konwencja o prawach dziecka, Dz. U. 1991, nr 120, poz. 526. 
2. Państwa-Strony będą podejmowały wszelkie właściwe środki zapewniające, aby dyscyplina szkolna była stosowana w sposób zgodny z ludzką godnością dziecka i z niniejszą konwencją.

3. Państwa-Strony będą popierały i rozwijały międzynarodową współpracę w dziedzinie oświaty, w szczególności w celu przyczyniania się do zlikwidowania ignorancji i analfabetyzmu na świecie oraz ułatwienia dostępu do wiedzy naukowo-technicznej i nowoczesnych metod nauczania. W tym zakresie należy w szczególności uwzględniać potrzeby krajów rozwijających się.

\section{Artykuł 29}

1. Państwa-Strony są zgodne, że nauka dziecka będzie ukierunkowana na:

a) rozwijanie w jak najpełniejszym zakresie osobowości, talentów oraz zdolności umysłowych i fizycznych dziecka;

b) rozwijanie w dziecku szacunku dla praw człowieka i podstawowych swobód oraz dla zasad zawartych w Karcie Narodów Zjednoczonych;

c) rozwijanie w dziecku szacunku dla jego rodziców, jego tożsamości kulturowej, języka i wartości, dla wartości narodowych kraju, w którym mieszka dziecko, kraju, z którego dziecko pochodzi, jak i dla innych kultur;

d) przygotowanie dziecka do odpowiedzialnego życia w wolnym społeczeństwie, $\mathrm{w}$ duchu zrozumienia, pokoju, tolerancji, równości płci oraz przyjaźni pomiędzy wszystkimi narodami, grupami etnicznymi, narodowymi i religijnymi oraz osobami rdzennego pochodzenia;

e) rozwijanie w dziecku poszanowania środowiska naturalnego.

KonWENCJA O PRAWACH DZIECKA, jak i inne międzynarodowe akty

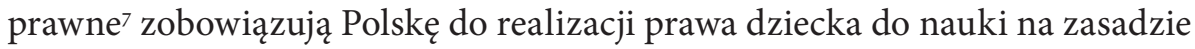
równych szans.

\section{Prawo do równości w edukacji i problem $\mathrm{z}$ jego uzasadnieniem}

Uwzględniając powyższe uwagi, w obszarze merytorycznym praw dziecka do edukacji, ogólne sformułowanie prawa do równości w edukacji może brzmieć w sposób następujący:

- $A$ jest równy wobec $B$ ze względu na prawo do edukacji wtedy i tylko wtedy, gdy: $A$ i $B$ są tożsame ze względu na posiadanie prawa do edukacji, tj. ze względu na powinność (moralną lub/i prawno-pozytywną) realizacji własności polegającej na byciu edukowanym (dalej: PRE).

Jak zostało wspomniane wcześniej, prawo do edukacji w niniejszym tekście rozumiane jest normatywnie, co oznacza, że właściwa analiza doty-

7 Na potrzeby niniejszego opracowania, ze względu na postawiony cel, nie przeprowadzono szczegółowej analizy wszystkich aktów prawa międzynarodowego dotyczących edukacji, a ograniczono się jedynie do wskazania podstawowych dokumentów w tej dziedzinie. Przeglądowe analizy w tym zakresie poczyniono m.in. patrz: P. Bała, Konstytucyjne prawo do nauki a polski system oświaty, Wydawnictwo von Borowiecky, Warszawa 2009, s. 149170. 
czy zdania: Powinno być tak, że podmioty edukacji są równe ze względu na prawo do niej lub, w innej stylistyce, prawo do edukacji powinno przysługiwać wszystkim w równym stopniu. Tak sformułowana zasada wydaje się zbyt mocna, trudno o jej pełną realizację; stanowić ona może zatem jeden z celów i wymóg nieustannego podejmowania zadań na rzecz jej realizacji.

Uzasadnienie zasady PRE nie jest rzeczą oczywistą samo przez się. W niektórych kulturach (np. w muzułmańskiej) prawo do równości w edukacji bywa kwestionowane; dziewczynki nie mają tych samych praw co chłopcy; zdarza się, że wręcz zakazuje im się edukacji. Również pewne fragmenty BıbLII można traktować jako odrzucenie zasady $\mathrm{PRE}^{8}$. Podobnie whistorii filozofii odnajdziemy wsparcie dla zasady przeciwnej do PRE. Jako przykład służyć może stanowisko Platona i Arystotelesa, głoszące niezdolność, z racji słabszych niż w przypadku mężczyzn możliwości intelektualnych, kobiet do życia kontemplacyjnego (teoretycznego) ${ }^{9}$. Tezy takie, mimo że rzadko, to jednak zdarzają się być wyrażane w dyskursie politycznym. W tym kontekście np. skrajny ruch feministyczny stwierdza zachodzenie niepisanych zasad czy stereotypów (przemoc symboliczna), powodujących nierówności ze względu na płeć. Z pewnością w większym stopniu reprezentowane jest jednak (szczególnie współcześnie) odmienne stanowisko, wspierające PRE. W BIBLII odnajdziemy fragmenty odwołujące się do przyrodzonej równości wszystkich ludzi, w filozofii m.in. koncepcję edukacji Immanuela Kanta (wyrażoną w dziele O PEDAGOGICE ${ }^{10}$ ), koncepcje praw natury (m.in. John Locke ${ }^{11}$ ) czy sprawiedliwości społecznej (John Rawls ${ }^{12}$ ). Współcześnie ważne w tym względzie stanowisko reprezentuje Joel Feinberg, który prawa dziecka do edukacji (przysługujące każdemu dziecku w równym stopniu) określa jako jedno z tzw. praw do otwartej przyszłości (rights to an open future, anticipatory autonomy rights) ${ }^{13}$. To prawa specyficzne, właściwe wyłącznie dzieciom, których gwarantem mają być zarówno rodzice,

8 „Kobieta niech się uczy w cichości i w pełnej uległości; Nie pozwalam zaś kobiecie nauczać ani wynosić się nad męża; natomiast powinna zachowywać się spokojnie. Bo najpierw został stworzony Adam, potem Ewa. I nie Adam został zwiedziony, lecz kobieta, gdy została zwiedziona, popadła w grzech; Lecz dostąpi zbawienia przez macierzyństwo, jeśli trwać będzie w wierze i w miłości, i w świątobliwości, i w skromności”, I Tm 2,11-15.

9 „Tak jest [...] z rodzajem męskim i żeńskim, [...] pierwszy jest z natury silniejszy, drugi słabszy; toteż ten panuje a tamten mu podlega", Arystoteles, Polityka, przekł. L. Piotrowicz, http://katedra.uksw.edu.pl/biblioteka/arystoteles_polityka.pdf [20.02.2015]. Zob. I. Kant, O pedagogice, przekł. D. Sztobryn, DAJAS, Łódź 1999.

${ }^{11} \quad$ Zob. J. Locke, Dwa traktaty o rządzie, przekł. Z. Rau, PWN, Warszawa 1992.

${ }_{12}$ Zob. J. Rawls, Teoria sprawiedliwości, przekł. M. Panufnik, J. Pasek, A. Romaniuk, PWN, Warszawa 2013.

13 Zob. J. Feinberg, Freedom and Fulfillment: Philosophical Essays, Princeton University Press, Princeton 1992; zob. również modyfikacja jego stanowiska w: C. Mills, The Child's Right to an Open Future?, "Journal of Social Philosophy” 2003, vol. 34/4, XII, s. 499-509. 
opiekunowie, jak i państwo. Związane są one z przekazem takiej wiedzy oraz kształtowania tych umiejętności i kompetencji moralnych, które w przyszłości umożliwić mają dziecku realizację pełni praw przysługujących osobom dorosłym.

Zatem zarówno na rzecz równości jak i nierówności w edukacji odnaleźć można odpowiednie argumenty. Mogą one mieć charakter religijny (odwołujące się do zasad danej religii), jak i filozoficzny (odwołujące się do natury ludzkiej), czy szerzej, światopoglądowy. Zdania stanowiące przesłanki tych argumentów to zdania nie opisowe, ale normatywne, stwierdzające, jak być powinno. Dla przykładu, w religii $\mathrm{R}$ obowiązuje zdanie, będące wyrazem woli Boga tej religii: „Każdemu człowiekowi należy się szacunek”, z tego zdania i metanormy religijnej: „Należy postępować zgodnie $\mathrm{z}$ wolą uznawanego Boga”, wynika zdanie: „Powinno się przestrzegać zasady, zgodnie z którą każdemu należy się szacunek”. Do tego typu zdań stosuje się tzw. Prawo Hume’a ${ }^{14}$. Głosi ono, że zdania normatywne nie wynikają ze zdań opisowych, a wyłącznie z innych zdań normatywnych (przynajmniej jedna przesłanka musi być normatywna) ${ }^{15}$. Jeśli zatem PRE ma charakter normatywny, musi odwoływać się do innych, bardziej ogólnych od niej norm (filozoficzne, religijne, światopoglądowe). Oznacza to jednocześnie, że przyjęcie omawianej zasady wiąże się z akceptacją pewnych wstępnych warunków o charakterze tez niedowodliwych, osadzonych w określonej filozofii, religii, światopoglądzie ${ }^{16}$.

14 D. Hume, Traktat o naturze ludzkiej, t. 2, przekł. Cz. Znamierowski, PWN, Warszawa 1963, S. 259-260.

15 Należy zaznaczyć, że jest to najczęściej przyjmowana, ale nie jedyna interpretacja „Prawa Hume'a”. W innych wersjach uznać można m.in. fakt zachodzenia związku logicznego między zdaniami opisowymi a normatywnymi. Dyskusja na ten temat zob. m.in.: M. Rutkowski, Rola rozumu w decyzjach moralnych: Etyka Davida Hume'a, Wydawnictwo Uniwersytetu Wrocławskiego, Wrocław 2001; P. Makowski, Gilotyna Hume’a, „Przegląd Filozoficzny - Nowa Seria” 2011, $\mathrm{nr} 4$ (76).

16 Tezę tę wyjaśnia się tu następująco: jeśli w uzasadnieniu PRE należy odwołać się do norm wyższego rzędu, to (zakładając przyjętą interpretację „Prawa Hume’a”) albo (a) uzasadnianie będzie przebiegać w nieskończoność, albo (b) normy wyższego rzędu, jako zdania nie-opisowe, uznamy za nieposiadające wartości logicznej, albo (c) normy wyższego rzędu uznamy za nieredukowalne i posiadające wartość logiczną. (a) jest kontrintuicyjne i problematyczne z powodów praktycznych; (b) jest wyrazem stanowiska nonkognitywistycznego (antyrealizm etyczny); (c) jest wyrazem stanowiska kognitywistycznego (realizm etyczny). Stanowiska (b) i (c) są w równej mierze obecne w metaetyce i co do ich trafności trwa dyskusja. Autorzy, mając świadomość problemów związanych z (b), zakładają je w niniejszych rozważaniach, uzasadniając to między innymi faktem pluralizmu systemów etycznych i brakiem jednoznacznych kryteriów ich wyróżnienia i oceny. Szczegółowa analiza wykracza jednak poza ramy niniejszego artykułu. Na ten temat zob. m.in.: K. Saja, Filozoficzne źródła antyrealizmu etycznego, „Roczniki Filozoficzne” 2014, nr 1; A. Kuźniar, Język i wartości: racjonalność akceptacji ekspresywizmu metaetycznego, Semper, Warszawa 2009. 
Aby to uzasadnić, należy zatem przyjąć inną niż wnioskowanie oparte na niepodważalnych prawdach, drogę. Jest to droga minimalistyczna. Polega na wskazaniu warunków wystarczających ${ }^{17}$ dla uznania PRE; o ile przyjmiemy te warunki, to na mocy reguł logiki klasycznej musimy również przyjąć ich konsekwencje. W powyższych przykładach zarysowane zostały warunki odwołujące się do filozofii, religii, światopoglądu. Nie jest to jednak jedyny kontekst uznania omawianej zasady. Pomijając kwestie współzależności światopoglądu i prawa pozytywnego, również i ono (tj. prawo) w sposób normatywny wpływa na stosunek do PRE. Krótko mówiąc, jeśli uznajemy prawo danego państwa (regulujące m.in. relacje w dziedzinie edukacji i w znacznej mierze determinujące kształt systemu oświaty), jednocześnie uznać (i stosować) musimy obowiązujące w nim normy ${ }^{18}$. Dalsza część rozważań poświęcona będzie temu, w jaki sposób prawo pozytywne może stanowić uzasadnienie dla PRE.

\section{Prawo do równości w edukacji w prawie polskim i bariery w jego realizacji}

Podjęte w poprzednich częściach artykułu rozważania zostaną w tym miejscu dookreślone do ustawodawstwa polskiego, aby na tym tle nakreślić przypadki weryfikujące zasadę PRE.

W polskim porządku prawnym zasada powszechnego prawa do edukacji została wyartykułowana już w Ustawie Zasadniczej. Artykuł 70 Konstytucji Rzeczypospolitej Polskiej w punktach 1, 2 i 4 gwarantuje wszystkim prawo do nauki ${ }^{19}$ :

Artykuł 7o

1. Każdy ma prawo do nauki. Nauka do 18 roku życia jest obowiązkowa. Sposób wykonywania obowiązku szkolnego określa ustawa.

2. Nauka w szkołach publicznych jest bezpłatna. Ustawa może dopuścić świadczenie niektórych usług edukacyjnych przez publiczne szkoły wyższe za odpłatnością.

3. [...]

4. Władze publiczne zapewniają obywatelom powszechny i równy dostęp do wykształcenia. W tym celu tworzą i wspierają systemy indywidualnej pomocy

${ }_{17}$ Warunkiem wystarczającym zdania $B$ jest takie zdanie $A$, które jeśli jest prawdziwe, to $B$ również jest prawdziwe.

$18 \mathrm{~W}$ niniejszym artykule pomija się szeroko dyskutowane w metaetyce kwestie internalizmu, tj. m.in. relacji między racją, motywacją a działaniem, jak i zagadnienia związane z obywatelskim nieposłuszeństwem. Zainteresowanego Czytelnika autorzy odsyłają m.in. do: W. Janikowski, Naturalizm etyczny we współczesnej filozofii analitycznej, Semper, Warszawa 2008, s. 105-119; M. Kaczmarczyk, Niepostuszeństwo obywatelskie a pojęcie prawa, Oficyna Naukowa, Warszawa 2010.

19 Konstytucja Rzeczypospolitej Polskiej, Dz. U. 1997, nr 78, poz. 483. 
finansowej i organizacyjnej dla uczniów i studentów. Warunki udzielania pomocy określa ustawa.

Konstytucyjne zapisy dotyczące prawa do nauki zostały doprecyzowane i zabezpieczone w ustawie $\mathrm{z}$ dnia 7 września 1991 roku o systemie oświaty oraz waktach wykonawczych do tejże ustawy. Treść normy stanowiącej prawo do edukacji interpretować można w sferze materialnej w dwóch płaszczyznach: prawa pozytywnego oraz w kategorii wolności do nauki (prawo negatywne $)^{20}$. W pierwszej płaszczyźnie istota tego prawa dotyczy obowiązku ustawodawcy wobszarze zabezpieczenia możliwości realizacji prawa do nauki na zasadach powszechnego i równego dostępu (art. 70 ust. 4 KonstyTUCJI RP). Proklamowanie prawa do nauki jako prawa pozytywnego nakłada na ustawodawcę konkretne obowiązki w zakresie stworzenia i utrzymania niezbędnej infrastruktury dla procesów edukacji oraz zapewnienia jej odpowiedniego poziomu. Działania władz publicznych zabezpieczające zasadę powszechnego prawa do edukacji polegać powinny m.in. na odpowiednim ukształtowaniu sieci szkół publicznych, w tym także szkolnictwa specjalnego, a w określonych warunkach przewidzianych ustawą - zagwarantowaniu bezpłatnego dowozu dziecka do przedszkola czy szkoły ${ }^{21}$; tworzeniu systemu pomocy materialnej dla uczniów, a także zabezpieczeniu rodzicom możliwości wyboru dla swoich dzieci szkół innych niż publiczne. Zasadniczą implikacją zasady PRE powinno być zatem podjęcie przez państwo działań w zakresie tworzenia warunków administracyjnych i prawnych do powstawania i funkcjonowania szkolnictwa niepublicznego. Konkretnym przejawem realizacji przez ustawodawcę polskiego zasady PRE jest nałożenie na odpowiednie organy państwowe kompetencji kontrolnych w zakresie przestrzegania realizacji prawa do nauki oraz praw dzieci w edukacji, zabezpieczenie formalnoprawne procesów finansowania oświaty, a także dopracowanie koncepcji zabezpieczenia socjalnego realizacji prawa dziecka do edukacji.

Analizy sfery normatywnej dotyczącej zasady równości w edukacji doprowadzają do konkluzji, wskazującej, że jeżeli organy państwa poprzez swoje aktywne działanie lub zaniechanie nie uczynią nauki powszechnie dostępnej na warunkach doprecyzowanych w ustawie, naruszone zostaną normy prawa pozytywnego oraz nie będą spełnione przesłanki pozwalające przyjąć zasadę PRE. Sytuacje takie określić możemy mianem barier w realizacji zasady równości na gruncie polskiego systemu oświaty. Bariery te przybierać

20 Wolność nauki, nazywana niekiedy prawem negatywnym, zakłada zakaz ingerencji władzy w określone obszary tej dziedziny życia.

${ }^{21}$ Art. 17 ustawy o systemie oświaty. 
mogą różnego rodzaju kształt. Badania własne autorki ${ }^{22}$ podejmujące tę problematykę wskazują, że przeszkody w realizowaniu zasady PRE związane są z zaistnieniem sytuacji, okoliczności czy zachowań, które doprowadzają do znacznych utrudnień, czy wręcz zaniechań w realizowaniu tej podstawowej normy prawnej. Co istotne, wiele z powstałych sytuacji nierealizowania czy utrudnień w realizacji prawa do edukacji nie jest jednoznacznie rozpoznanych i zdefiniowanych w ramach literatury przedmiotu jako przyczyny niepowodzeń szkolnych czy nierówności oświatowych ${ }^{23}$. Okoliczności te wskazywać mogą na miękkość prawa do edukacjii ${ }^{24}$. Więcej, nierealizowanie tego prawa dziecka często nie jest postrzegane społecznie w kategoriach naruszeń prawa stanowionego. Dzieci napotykają poważne utrudnienia w realizacji swoich praw edukacyjnych, czy wręcz są wykluczane z systemu oświaty, co jednak nie jest analizowane jako pozbawienie i naruszenie prawa stanowionego. Sytuacje te natomiast często rozpoznawane są jako nadopiekuńczość rodziców względem dziecka (dzieci przebywają w domu z powodów niezwiązanych z rzeczywistą niemożnością uczestniczenia w zajęciach edukacyjnych), zaradność dziecka (podejmowanie pracy zarobkowej zamiast uczestniczenia w procesach edukacyjnych), czy przejmowanie za dziecko odpowiedzialności za życie rodziny (praca w gospodarstwie, opieka nad młodszym rodzeństwem uniemożliwiająca chodzenie do szkoły). Takie społeczne postrzeganie absencji szkolnej powoduje, że nie podejmuje się konkretnych działań skierowanych na usunięcie tak powstałych barier edukacyjnych.

\section{Uwagi końcowe}

Kończąc podjęte rozważania, warto wrócić do przedstawionej definicji równości w zakresie prawa do edukacji; $A$ jest równy wobec $B$ ze względu na prawo do edukacji wtedy i tylko wtedy, gdy: A i B sq tożsame ze względu na posiadanie prawa do edukacji, tj. ze względu na powinność (moralna lub/i prawno-pozytywna) realizacji własności polegającej na byciu edukowa-

22 Por. M. Kozak, Prawo dziecka do edukacji. Założenia pedagogiczno-prawne i bariery realizacyjne, Biuro Rzecznika Praw Dziecka, Warszawa 2013.

23 Ibidem, s. 134-142.

24 Klasyfikacja praw przyjęta przez M. Czerepaniak-Walczak. Autorka proponuje podział praw na „miękkie” (tzn. takie, za które nie grożą określone sankcje karne, wymienia tu prawo do prywatności, prawo do wypoczynku i czasu wolnego, a także prawo do autoekspresji) i „twarde” (na straży których stoją sankcje karne), patrz: M. Czerepaniak-Walczak, Aspekty i źródła profesjonalnej refleksji nauczyciela, EDYTOR, Toruń 1997, s. 65-78; eadem, Edukacja: Quinta essentia uśmiechu dziecka (o roli edukacji w urzeczywistnianiu praw dziecka), „Forum Oświatowe” 2000, nr 1 (22), s. 55-64; eadem, Prawo dziecka do rozwoju, [w:] Prawo dziecka do zdrowia, J. Bińczycka (red.), Oficyna Wydawnicza Impuls, Kraków 2007, s. 134-136. 
nym. Ta równość, aby przestała być jedynie kategorią powinnościową, musi być zabezpieczona przez konkretne instrumenty administracyjno-prawne, związane z możliwością realizacji sankcji prawnej za naruszenie tejże równości. Takie instrumenty przewidziane są w prawie oświatowym i zabezpieczone $\mathrm{w}$ ramach postępowania sądowo-administracyjnego. Warto także dookreślić, podejmując kwestie równości w realizacji prawa do edukacji, iż zasada ta gwarantuje wszystkim podmiotom możliwość zabezpieczenia owej własności, polegającej na „byciu edukowanym”. Stąd też możemy odnaleźć $\mathrm{w}$ prawie pozytywnym przepisy stanowiące o tworzeniu w ramach systemu oświaty w Polsce szkolnictwa specjalnego, realizacji i zabezpieczeniu specjalnych potrzeb edukacyjnych uczniów, o nauczaniu indywidualnym, wspieraniu ucznia zdolnego, nauczaniu domowym, czy zabezpieczeniu realizacji prawa do edukacji dla dzieci cudzoziemców czy obcokrajowców.

Warto zwrócić uwagę na jeszcze jedną kwestię wyznaczającą nową perspektywę w rozumieniu zasady równości wedukacji. Poddając analizie orzecznictwo Europejskiego Trybunału Praw Człowieka w dziedzinie edukacji, odnaleźć możemy stanowisko wskazujące, że niedostatecznie rozbudowany system edukacji na poziomie podstawowym lub niska jej jakość interpretowane są jako pozbawienie dziecka prawa do nauki ${ }^{25}$. Takie stanowisko orzecznictwa Trybunału stawia przed systemem prawa nowe wyzwania związane już nie tylko z zabezpieczeniem faktycznej możliwości realizacji zasady równości w edukacji, ale także konieczność normatywnego zdeterminowania obszaru jakości pracy placówek edukacyjnych. To jednak bardziej skomplikowana sprawa niż budowa nowych szkół i dbanie o infrastrukturę oświatową, a pierwsze nowelizowane pod tym kątem akty normatywne w zakresie nadzoru pedagogicznego wskazują, że realizacja zasady PRE jest wyzwaniem nie tylko organizacyjno-prawnym, ale wymaga zmiany i doprecyzowania kategorii myślenia o jakości w procesie edukacji, o zagadnieniach jej zabezpieczania i pomiaru. Ten aspekt mógłby stać się inspiracją do podjęcia w tym obszarze badań naukowych. Sam jednak wykracza poza ramy niniejszego artykułu.

\section{BIBLIOGRAFIA}

Arystoteles, Polityka, przekł. L. Piotrowicz, http://katedra.uksw.edu.pl/biblioteka/arystoteles_polityka.pdf.

Bała P., Konstytucyjne prawo do nauki a polski system oświaty, Wydawnictwo von Borowiecky, Warszawa 2009.

Feinberg J., Freedom and Fulfilment: Philosophical Essays, Princeton University Press, Princeton 1992.

25 M. A. Nowicki, Europejski Trybunał Praw Człowieka. Orzecznictwo, t. 2, Zakamycze 2002, s. $367-374$. 
Hart S., Cohen C. P., Erickson M. F., Flekkøy M., Prawa dzieci w edukacji, przekł. S. Pikiel, GWP, Gdańsk 2006.

Hume D., Traktat o naturze ludzkiej, t. 2, przekł. Cz. Znamierowski, PWN, Warszawa 1963.

Kant I., O pedagogice, przekł. D. Sztobryn, DAJAS, Łódź 1999.

Konstytucja Rzeczypospolitej Polskiej, Dz. U. 1997, nr 78, poz. 483.

Konwencja o prawach dziecka, Dz. U. 1991, nr 120, poz. 526.

Kozak M., Prawo dziecka do edukacji. Założenia pedagogiczno-prawne i bariery realizacyjne, Biuro Rzecznika Praw Dziecka, Warszawa 2013.

Locke J., Dwa traktaty o rządzie, przekł. Z. Rau, PWN, Warszawa 1992.

Mikosz J., Prawo do nauki, [w:] Prawa człowieka. Model prawny, R. Wieruszewski (red.), Ossolineum, Wrocław 1991.

Mills C., The Child's Right to an Open Future?, „Journal of Social Philosophy” 2003, vol. 34/4, XII.

Rawls J., Teoria sprawiedliwości, przekł. M. Panufnik, J. Pasek, A. Romaniuk, PWN, Warszawa 2013.

\section{SUMMARY}

\section{Philosophical and legal aspects of justification of the right for equality in education}

In the article the analysis of the issues of justification of the right for equality in education has been presented (understood as the right for equality in being educated). Presented analyses refer to some issues related to this topic, such as the problem of relational and normative notions of equality and the right for education; the problem of the possibility of justifying the right for equality in education; justification of that law in the Polish and international legislation. Selected historical issues (i.e. attempts to justify the right for equality in education on the basis of the broader philosophical thoughts) and practical issues (i.e. the barriers in its implementation) have been also emphasized.

KEY WORDS: the right for equality in education, law versus education, the right for education, normativity of education, legal aspects of education, philosophical aspects of education. 